\title{
Scarce skills expatriates in South African universities: Rhetoric and realities of the "Messianic" academics
}

\author{
MP SEBOLA $A^{l}$
}

\begin{abstract}
This article investigates the reason for the continued scarce skills shortage, despite the recruitment of expatriates in academic institutions as an intervention measure. It argues that while the Human Resources Departments in South African universities motivate for the appointment of expatriates in the development of scarce skills, little monitoring is done to determine the effectiveness of this objective and, often, no performance instrument exists for such personnel. As such, the scarce skills to be developed continue to be wanting in the country. This article is conceptual and uses literature to argue about the hypothetical relation between the lack of a monitoring tool for expatriates and the continued scarce skills problems that universities cannot address. It concludes that the continued lack of a performance-monitoring instrument in South African universities for contracted expatriates will not solve the skills shortage problem experienced in South Africa.
\end{abstract}

Keywords: expatriates, scarce skills, performance monitoring, universities, South Africa

\section{Introduction}

The reasons for the migration of skilled employees to foreign countries may differ from one employee to the other; however, Dayton-Johnson, Pfeiffer, Schutler \& Schwinn (2009) listed the political, economic and environmental problems as major causes. Of the utmost significance is that it is noted that individuals develop their skills using their country's resources to contribute to the economic growth of own country and to compete with other neighbouring countries and continents in that regard. The migration of skilled employees of both developing and developed countries is a cross path and with different perceptions of those interested in factors influencing it. The immigration of skilled employees from developing countries to better countries may be influenced by the push and pull factors, while those migrating from developed countries to developing countries are mostly influenced by the desire to explore and learn cultural differences. On the other hand, the receiving country regulates the entrance and employment of the immigrant employee to ensure that their presence would bring about development of scarce skills in the local community. In the South African academia, this is a precondition of employment in which Human Resources Departments have to convince the Department of Home Affairs that the employee's skills are indeed necessary and can make a significant contribution to the local skills required. A major research question raised in this article is: Do South African universities have a performance

School of Economics \& Management, University of Limpopo, Private Bag X1106, Sovenga, 0727, South Africa, E-mail: mokoko.sebola@ul.ac.za 
instrument with which to measure the performance of such individuals and the effect of the skills transferred to locals?

\section{Conception of expatriate}

The concept of expatriate currently has no common meaning and application in literature. Vogel, Van Vuuren \& Millard (2008) and Gupta, Dasari \& Dasari (2012) define it as a term that refers to people who move across the national border(s) to another country to pursue their professional, economic and financial goals. However, it can be argued that the economic and financial goals of expatriates in foreign countries supersede other intentions. Most literature associates the task of expatriates with failure and not with the achievement of positive results. While the application of this concept may differ significantly from being a parent country national, a third country national or an inpatriate, the most common understanding is that it is a concept referring to a skilled professional from another country using his or her skills in a foreign country. In the context of this article, the concept is used to refer to the use of foreign academic experts in universities in an attempt to solve skills shortage and transfer of skills to the locals so that they can sustain themselves after the departure of the service provider. However, the concept has been used commonly by the multinational companies that sent people from their own country to further business interests on foreign soil.

Gafhoor, Khan, Idress, Javed \& Ahmed (2011) use the term "expatriate" to refer to a highly skilled worker with unique expertise who is sent to work in another unit of the company located in a foreign country. The reference to expatriates as high skilled is also a contested matter since Harvey (n.d.: 1-11) argues that a variety of high-skilled categories and interpretations thereof exist in migration literature. The use of the term "high-skilled category" may differ from one country to the other. Harvey (n.d.: 10) used it to refer to a British citizen holder of a three-year qualification and three years of paid or unpaid work after obtaining such qualification. From a business literature perspective, it is argued that skilled expatriates are indeed able to transfer knowledge and skills to the local beneficiaries. However, thus far such theory is not shared equally by those in the South African academic circles about the role of academic expatriates in local skills transfer and development.

\section{Scarce skills and causes of shortage in South Africa}

The concept of scarce skills is defined as those occupations in which there is a scarcity of qualified and experienced people, currently or anticipated in the future, either (a) because such skilled people are not available or (b) they are available but do not meet employment criteria (Isset Seta, 2011: 48; South Africa, 2014: 8). The Scarce Skills 2014 list compiled by the Department of Education in South Africa showed the specific skills in the categories of engineering, medical and health sciences, maths and science teaching, ICT, retail, agriculture, finance, technicians as well as urban and regional planners. In South Africa, such problems are still agued to be closely linked to the past education system that was deeply rooted in apartheid policies, which promoted better education benefits to the white minority than the benefits for the majority of the African populace. It is the injustices of the past education system that hamper the present education from playing a meaningful role in the economic growth of the country.

South Africa's Gross Domestic Product (GDP) is below potential when compared to the global economies reported between 2008 and 2012 (OECD, 2013: 11). According to 
Trading Economics (2014), its GDP value represent $0.62 \%$ of the world economy, however, some economic predictions see the prospects of increase in both GDP and income in the near future. The teaching quality and produce of the teaching products are a matter of concern for economic growth in the country. The Global Competitive Report of 2013 ranked South Africa at position 140 out of the 144 listed countries in terms of the quality of the educational system of the country (World Economic Forum, 2013: 1-5). This questions the quality of the education system, which is responsible for scarce skills in the employment sector of the country. This forces the country to rely on academic labour supply from the global community. On the other hand, it is acknowledged in the educational discourses that teacher development in South Africa has always been considered a critical matter of debate in and before the post-apartheid South Africa (Rubichund \& Steyn, 2014). South Africa's education system is characterised by poor schooling and poor performance in English, maths, science, life skills, ICT skills and business acumen (Isett Seta, 2011: 48). Davids (2009), on the other hand, argued that the quality of education does not match the international standards and is even lower than some less developed countries in Africa. To this extent, South Africa's education system continued to be regarded as being of poorer quality than those of Zimbabwe, Zambia or Tanzania, even though these countries are experiencing economic slowdown. Gaidzanwa (n.d.) indicated that in 1991, 25\% of highly skilled Zimbabwean academics and professionals emigrated to South Africa, Canada, USA and Australia to evade the scourge of economic decline in their country. The quality of education, on the other hand, cannot be dissociated from the ability and skills obtained by the teachers to perform the honourable task of teaching, which is often considered a calling. It is argued that it is indeed the quality of the training received by teachers that determines the quality of the products to be produced by those teachers. As late as in 2001, South Africa still had approximately 85 000 teachers with professional training of less than three years, which threatened the provision of quality education to the post-apartheid South African children needing it.

\section{Recruitment and appointment of academic expatriates}

South Africa as a country in Africa is said to be experiencing serious challenges in terms of recruitment, selection and retention of academics (Bernard, 2012); therefore, there is a need to employ academic expatriates to close the gap of its national human resources challenge. Dumont \& Lemaitre (2005: 15) revealed that, despite the shortages of skills by other African countries, including South Africa, Africa experiences the highest brain-drain of highly skilled people in the globe. On the other hand, it is believed that it is the shortage of skills in South Africa that threatens the country's potential to achieve the 6\% growth rate (Breier, 2009: 1). The skills shortage is blamed on poor quality education provided by the former apartheid government to blacks.

In South Africa, expatriates in academia are said to be welcomed with open arms in order to close the skills shortage gaps in human resources. According to Del Rey \& Mignin (2010: 49-52), the employment and recruitment of expatriates is governed in terms of the Immigration Act, 2002 (Act No. 13 of 2002) which regulates the foreign nationals' admission to and employment in the country. In terms of this Act, employers are expected to implement the provisions. This affirms to government that the employment of the foreign nationals is in accordance with the skills category shortage in the country. The South African employers are by law expected to enforce the provisions of the Immigration Act without compromise, failing which they would be open to prosecution. However, that has never proven to be real 
in the employment of foreign expatriates, either in the academic world or in other sectors of the labour market in South Africa. Most South African managers in academia have considered foreign expatriates in the academic world to be more cooperative and manageable than the locals who can compete for managerial positions in these institutions. This is mostly influenced by the fact that most of these expatriates in academia are mainly from Africa and not even from countries that are doing better in the continent; and, those include Ghana, Zambia, Zimbabwe, Nigeria and Cameroon.

An academic expatriate of Asian, European or Mongolian origin is likely to be treated better than those from Ghana, Zambia or Zimbabwe because of the associated economic status of the immigrant. The selection and appointment of expatriates, especially from Africa, are not only a problem for South African citizens who often treat these expatriates in an uncivilised manner because of their feeling of remorse for lost positional opportunities, but are also a problem for the expatriates who often take lower salaries despite the significance of the position they have opted to occupy. According to Tati (2008), this may insinuate the perception of cheap labour and abuse of defenceless academics from other parts of Africa by the South African labour market. That, on the other hand, may create a problem for the South African government as appointed academic expatriates are likely to make no positive impact on the education system and they need to be assisted. On the other hand, from a legal perspective, the foreign nationals are not easily favoured by the South African laws when it comes to recruitment and appointment to employment positions. Despite the harsh realities that they can only be appointed in positions where there is a critical shortage of skill, South Africa still faces its own ghosts of satisfying the objectives of the Employment Equity Act, 1998 (Act No. 55 of 1998) which are far from being achieved. Often an academic expatriate might not even qualify to make it in the preliminary shortlisting because he or she does not belong to the category of a designated group. Some criticism of the South African policies of equity offered by Mulenga \& Van Lill (2007), is that such policies do not promote the chances of employment and recruitment of foreign nationals and therefore are not geared towards the alleviation of the skills shortage in the country. This is also in line with the observations that the verifications done by the Department of Home Affairs before employing a foreign national are quite difficult. To a particular extent, even academic expatriates who are favoured by the appointment panels are often disappointed when the Department of Home Affairs is not satisfied with the necessity to appoint the preferred candidate.

Authors like Voicu \& Vlase (2014) indicated that immigrants should accept the reality of facing both subjective and objective barriers based on individual and labour-market characteristics. However, from a global perspective there is a general perception that countries are having difficulty to attract good and right talents to perform in their organisations (Tarique \& Schuler, 2012: 12). Such perception may be exaggerated to a particular extent in some countries' statistics and often for political sympathy or to justify unnecessary expatriate appointments. There are often some exaggerated skills shortage in South Africa, which cannot be empirically verified other than from perceptive studies whose methodological frameworks cannot even be justified. In 2010, the Higher Education Information Management System (HEMIS) of South Africa released statistics of the distribution of foreign staff academics in South African Universities (figure 1). 
Figure 1: Distribution of foreign staff across regions, 2005-2008

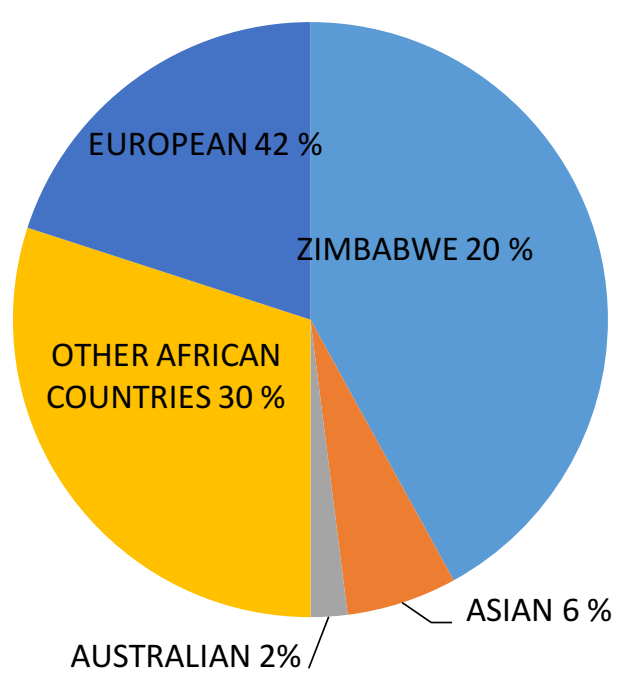

The figure above demonstrates a highest proportion of academic expatriates in South Africa that come from African countries (50\%). The second largest chunk of the expatriates comes from European countries (42\%) with the smallest percentage of 2\% from Australia and 6\% from Asia. The biggest portion of the European expatriates is concentrated in universities such as Witwatersrand, Rhodes, University of the Western Cape and University of Pretoria. The highest percentage of academic expatriates from Africa is likely to be attracted in former Bantustan universities. The latter, however, trying their best to promote excellent academic research and teaching as required by the country, are often not succeeding in that regard because of a skills shortage. To a certain extent, even the academic expatriates they attract are not the best in their field as compared to those attracted by the former advantaged South African universities. Such limitation becomes more visible in a situation where such employed expatriates' performance is not measured and in this way, the status quo of skills shortage in the country is maintained. It is often argued that since the start of South Africa's recruitment drive of scarce skills little seems to have changed in the human resources advancement of academic institutions in the 20 years after apartheid. The expatriates that retired from such academic institutions often do that without having left or developed the locals to take over the programmes on their own.

\section{Performance management of academic expatriates in South African Universities}

The concept of performance management (which replaced performance appraisal in many organisations because of the fact that the latter was process-oriented) adopted because it is mostly results-oriented and seeks for operational effectiveness through better use of resources and results (Toppo \& Prusty, 2012; Mbua \& Sasisar, 2013; Swanepoel, Botha \& Mangonyane, 2014). More than that, performance management in universities is required for public accountability, responsiveness, effectiveness and efficiency (Mapesela \& Strydom, 2012: 1-4) which should satisfy government and the public. The management and measurement of performance of academics in South African universities rarely exist or does not exist at all as far as performance practices are concerned. The minor performance appraisal systems that exist in some South African universities are not believed to be well 
executed and satisfactory to employees (Molefe, 2012; Toppo \& Prusty, 2012; Reguri \& Lakko, 2012). The non-existence of or the improper use of such tools in the academic arena of South African universities is a weakness which benefits the performance of academic expatriates that are appointed solely to ensure transference of skills for a particular time frame. Thus far, the issue of academics' performance in South African higher education institutions received less attention from government and policy makers (Molefe, 2011), and as such it remained ignored as a popular practice in academic institutions. Performance management in South Africa is a contested academic discourse that is very critical and has not been easy to implement in either the public service or private sector. Several pieces of literature on performance management suggested that the initiative of performance management in South African organisations relate it more to monetary incentive for employees than a developmental tool as envisaged by human resources scholars and practitioners. Therefore, it can be argued that where it is said to have been applied in South African organisations, they would have incurred expenditure that does not tie with the development expected from employees. The resultant effects have always been to create legitimate expectations of undeserved incentives by particular employees in the organisation.

Several studies conducted in South Africa have proven that performance management is a concept that is highly challenging in implementation (Manyaka, 2012) to the extent that organisations feel that it is better dumped as an organisational mission than practice. In South Africa, the concept is very difficult to implement in the public sector and service. In most government departments, it is implemented, but the success thereof is contested by many implementers and beneficiaries alike. In South African municipalities, the concept is so difficult that municipalities only apply it to senior management officials who are also not happy about its implementation. Performance management is probably not used for developmental purposes but rather for performance evaluation and should the expatriate be found wanting, the manager concerned should not have the contract renewed for continued service in the organisation.

\section{Is performance management of academic expatriates possible?}

Reguri \& Lako (2012: 3) indicated that the deployment of academic expatriates has become a significant aspect of international human resources development after World War 11. The establishment of universities in such countries has created a need for expatriates to provide skills development in those countries. Most countries have preferred the contractual agreements over those academic expatriates without necessarily looking at the long-term effects, and some academic expatriates have also identified such flaws and used their international mission for other purposes than local skills development. Local universities have little control over the situation because, as the saying goes: "Beggars can't be choosers". To this extent it is becoming increasingly difficult for local universities to even think of entering into performance-related contracts with expatriates because there is no competition for available positions in the skills shortage category. There is a dire need for such positions to be filled urgently, with no locals available to compete in the category. These positions are mostly in the field of accounting sciences, artisans and other engineering-related fields. Fadel \& Miller (n.d.: 6-8) argued that there is, similarly, a good relation between economic growth and education, and therefore an investment in education is a requirement for a developing country such as South Africa. Such investment is only possible if the country is capable of attracting good academic expatriates who will produce a crop of young South Africans that would contribute to the economic performance of the country. However, it may seem like 
there is a limitation in the country to achieve such objectives. This happens to the extent that performance management of academic expatriates becomes highly impossible to enforce. There are rhetorical questions and environmental realities that inhibit the universities' capacity to put academic expatriates on performance-related contracts that will force them to account for what they did differently in their period of employment. In most instances, South African universities advise them to stay until they qualify to apply for permanent residency so that they can permanently close the skills gap as local residents and not as expatriates. That ultimately releases them of their international assignments to contribute in the development of local economies.

\section{Rhetoric and realities of South African University environment}

It is very clear that the nature of the problem of academic expatriates in developing local skills in South Africa is full of rhetoric that is not in accordance with the realities of operations in the university environment. Such rhetoric includes, but is not limited to the following questions: Are the academic expatriates really needed to solve the skills problem? Does South Africa really have skills shortages? Are the academic expatriates interested in resolving skills shortages in South Africa? Is performance of academic expatriates necessary while on contract?

\section{Does South Africa really have skills shortages?}

Literature on this subject revealed that South Africa indeed has skills shortage in various areas (Breier, 2009: 1-6; Erasmus, 2009: 22-29) of the occupational categories. This skills shortage as identified and elaborated on has to be solved through an international recruitment drive in which academics from places other than South Africa can be encouraged to immigrate. What is interesting about this solution is that the messianic academics are mostly from other parts of Africa known for chronic economic, political and social problems. HEMIS (2010) reported that as in the year 2010, 50\% of academic expatriates in South African universities came from the African region. Despite the political rhetoric of apartheid, education and issues of poverty and inequality dominate all talks about the South African education system. Even during the apartheid era, South Africa had a well-developed educational infrastructural system consisting of 21 public universities, 15 technikons, 120 colleges of education, 24 nursing colleges and 11 agricultural colleges (Badat, n.d.: 11). With the post-1994 democratic South Africa and its rationalisation agenda of higher educational institutions, the process resulted in 11 "traditional universities", six universities of technology and six "comprehensive universities" (Department of Higher Education \& Training, 2014: 4), resulting in 23 universities in total. Three additional universities have been added to the family of South African tertiary educational institutions recently, namely: the University of Mbombela in Mpumalanga Province, the University of the Northern Cape and the Sefako Makgatho Allied Health University (a result of the de-merger of MEDUNSA from the University of Limpopo). Comparatively speaking, no country in Africa had a better public educational infrastructural development than South Africa. Many universities that exist in African countries are of recent origin as compared to South Africa, with most of them mushrooming after 2000 . 
Are the academic expatriates really needed to resolve skills problem?

Literature on expatriates' assignments revealed that they are always doomed to be a failure in any given international mandate (Selmer, 2006; Tahir \& Ismael, 2007; Vogel \& Van Vuuren, 2008) due to internal and external factors. With those limitations of expatriates being confirmed through various scientific studies on international migration, one may often ask a rhetorical question as to whether the academic expatriates are needed to solve the shortage of skills problem in South Africa? One can say yes, because literature confirms that there are shortages in specific skills, which dictate that due to insufficient interest by locals in that specific skills category an expatriate could be the solution. However, upon considering how well resourced the South African universities were during and after apartheid in comparison with those from other parts of Africa, it is impossible to agree on the messianic mission of academic expatriates from other parts of Africa. HEMIS (2010) showed that of the academic expatriates who were in South Africa in 2010, 20\% were from Zimbabwe and 30\% were from other parts of Africa. The 20\% Zimbabwean academic expatriates might be in South Africa because of the geographical proximity. However, even though the Zimbabwean government invested much in education since independence, their educational infrastructure development never competed with that of South Africa before and after apartheid. AnswersAfrica (2014: 1) revealed that of the top ten universities in Africa, seven are South African Universities (University of Cape Town, Rhodes, University of the Western Cape, University of South Africa, University of Pretoria, University of KwaZulu-Natal, Stellenbosch University and University of the Witwatersrand). The majority of the messianic academic expatriates do not come from universities that are listed in the top 100 African universities.

\section{Are the academic expatriates interested in skills shortages in South Africa?}

The intention to assist the host country by an academic expatriate is dependent on his or her reasons to seek employment in a foreign country in the first place. Literature confirms that their reasons differ; however, most of them are influenced by economic conditions and attractive offers of the host country. While academic expatriates of European origin might be attracted to South Africa because they want to explore, those from other parts of Africa might be attracted to South Africa by economic conditions that are better than those in their own country (Sebola, 2008). Harvey (n.d.: 17) reported that most high-skilled expatriates are likely not to go back home if they feel that the host country is providing better working conditions and incentives than their own. It is unlikely that the primary objective of academic expatriates from other countries is to put an end to the skills shortage in South Africa, because they regard it as a "Canaan". Their primary goal is to achieve economic gain and compete with the locals in the occupational categories mentioned as scarce skills.

\section{Is performance management of academic expatriates necessary while on contract?}

For a country that wants to solve a skills problem by using expatriates, performance management is deemed necessary. South Africa's school education and higher education system had numerous problems associated with the apartheid policy that seemed to have affected both the quality and quantity in some occupational skills (Odhav, 2009). It is true that the unequal and skewed educational opportunities provided by racist architects like $\mathrm{Dr}$ Hendrik Verwoerd, caused an irreparable disparity of shortage of skills in black South Africans. It can be argued that judging by the status of resourceful predominantly white universities in South Africa and the less-resourced black universities, the skills problem was 
arguably perpetuated in black universities. Like all other African countries, South Africa does not have a pool of academics that can use research to solve economic and social problems in the country (Mapesela \& Strydom, n.d.: 1-7). An engagement of expatriates that would be able to assist the South African society to solve that problem becomes a necessity. Such engagement can only be made effective if there is an appropriate performance measurement in place. Without an appropriate performance measurement of those engaged in closing the skills gap, the status quo is likely to remain.

\section{The messianic realities}

The concept of messianic as used in this article refers to academic expatriates attracted by working conditions in South African universities for purposes of assisting to reduce the problem of shortage of skills. While the purpose of the task is clear, South Africa remains a common village for everyone. Currently, it is not easy to assess whether the use of expatriates is absolutely positive for the local recipients. The most common problems were, developing own for own advantage, abuse of academic expatriates by local universities' management, utilised academic expatriates are not necessarily the best, academic expatriates are merely "fugitives" and not messianic.

\section{Developing own for own advantage}

The South African employment environment creates a competitive equal opportunity and advantage for everyone; however, Mulenga \& Van Ill (2007) view such advantage as limiting the potential of expatriates to participate fully in the human resources structure of the country. To a certain extent, this equal opportunity platform is exploited and ultimately benefits the wrong beneficiaries. Academic expatriates are said to produce research and publications when so required and when queried by local university authorities with respect to their worth. It is argued that, in response to such queries, they ultimately recruit students from their own countries and use the local resources to make a legitimate claim for their productivity, which ultimately does less to empower the locals, while benefiting individuals from their own countries. Volumes of research publications are produced and co-authored with scientists from their own countries and not with locals. Local universities may fail to see the growth of expatriates' academic selfish interests. On numerous occasions most of their publications concentrate on problems in their own countries. Post-graduate output in South Africa continues to be weak (Mapesela \& Strydom, n.d.: 2) and therefore the subsidy system introduced by the government is mostly research performance related (Ministry of Higher Education, 2004: 1-20; Wangege-Ouma \& Cloete, 2008; Odhav, 2009; Steyn \& De Villiers, n.d.: 11-51), which implies that the better the throughput rate, the better the funding at universities. This funding model is meant to improve research and to produce individuals that would assist with the socioeconomic development of the country. In this instance, the duty to develop locals is seen as a threat to an expatriate's position in the university and therefore local skills development remains a challenge.

\section{Abuse of academic expatriates by local university management}

The internationalisation of academia is currently a worldwide phenomenon and South Africa is not excluded from this. Currently, most of South Africa's recruits are sourced from Africa (Ghafoor, Faroog-Khan, Idrees, Javed \& Ahmed, 2011; Maharaj, 2011). These academic expatriates that are earmarked to assists with excellent teaching and research, are facing some 
challenges in the host country. Some of those challenges hinder their primary purpose for being in the host country. Reguri \& Lako (2012: 1-33) noted with concern the abuse and harassment of academic expatriates by local universities and used the South Pacific Higher Education as a case study in this instance. This problem as reflected in the South Pacific Higher Education University may be a reflection of the experience of academic expatriates at the global scale. This means that although academic expatriates are on an international mission of assisting in academic excellence, which should be done by means of teaching and research in host countries, they ultimately engage themselves in local universities' administrative politics, which leads to them suffering discrimination and harassments by opposing locals. In some host universities, expatriates are appointed in administrative positions that are meant for the locals because of their lack of bargaining power. Sebola \& Ngomane (2011) also noted this limitation by immigrants who say that they accept local offers with big salaries because the local people themselves cannot accept these jobs. This often leads to them being regarded as betrayers of the local citizens. Some local universities see them as easy to use objects in management because they would not query any decisions which a local manager would have queried if in administrative positions of a university.

\section{"Fugitives" and not "messianic"}

It is acknowledged that expatriates' failure rate is real in the foreign country (Qi \& Lange, 2005: 2) and international companies have experienced an eminent return with incomplete assignments at own home. The expatriates travel to provide services in foreign countries, mostly influenced by the desire to experience a different environment from their own home environment. South Africa is a unique country (Bentley, Habib \& Morrow, 2006: 10) based on its history, economy and the unusual composition of its population. These are some of the features making South Africa attractive to academic expatriates from Africa and other related continents. As such, not all academic expatriates come to South Africa because they have specific special skills to offer. In South African universities, the messianic mission is not believable because, in some cases, academic expatriates are appointed in positions that are not classified as scarce skills. They are often dominating in the universities' faculties of arts in which there are no scarce skills. Many times, this is the case because the country provides a peaceful fugitive home to expatriates. It is often clear that most academic expatriates in South African universities are not the best from their own country. Therefore, their messianic mission does not make a significant impact. Despite the engagements of academic expatriates in this assignment, skills shortage continues to be evidenced socially and economically in South Africa (Matteus, Allen-Ille \& Iwu, 2014) giving evidence that there is no justification of the messianic mission of the academic expatriates. Without a performance management contract, most academic expatriates stay in local universities until retirement age, leaving the status quo as it had been decades before they were given permanent citizenship. Therefore, the problem of skills shortage continues in the areas they were employed. Uncaring universities continue to employ them even after retirement to continue the legacy of nondevelopment of the locals.

\section{Conclusion}

This article has argued that there is a need for South African universities to appoint academic expatriates on performance-related contracts. Such contracts will assist in ensuring that 
academic expatriates work towards improving the knowledge-base for local university students and transfer the skills at the same time. The performance-related contracts will assist in closing the skills shortage gap in South Africa, which the academic expatriates are rarely able to solve currently. If well managed, the engagements of academic expatriates will help to improve teaching and research and the development of knowledge production that would produce individuals capable of socioeconomic problems.

\section{References}

Bentley, K., Habib, A. \& Morrow, S. 2006. Academic Freedom, Institutional Autonomy and Corporatized University in Contemporary South Africa. Pretoria: Council on Higher Education.

Bernard, B. 2012. Factors that determine academic staff retention and commitment in private tertiary institutions in Botswana: An empirical review. Global Advanced Research Journal of Management and Business studies, 1(9): 278-299.

Davids, B. 2009. The teacher development summit. The New Negotiator, 3(1): 1-8.

Del Rey, S. \& Mignin, R.J. 2010. International Labour and Employment Compliance Handbook. The Netherlands: Kluwer.

Dumont, J. \& Lemaitre, G. 2005. Counting Immigrants and Expatriates in OECD Countries: A New Perspective. New York: United Nations Secretariat.

Gaidzanwa, R.B. 2007. Alienation, Gender and Institutional Culture at the University of Zimbawe Feminist Africa 8: Rethinking Universities. Cape Town: African Gender Institute

Ghafoor, S., Khan, U.F., Idrees, F., Javed, B. \& Ahmed, F. 2011. Evaluation of expatriates performance and their training on international assignments. Interdisciplinary Journal of Contemporary Research in Business, 3(5): 335-351.

Harris, D.N. \& Sass, T.R. 2014. Skills, productivity and the evaluation of teacher performance. Economics of Education Review, 40: 183-204.

Harvey, W.S. n.d. Immigration and Emigration Decisions among Highly Skilled British Expatriates in Vancouver. Oxford: University of Oxford.

Maharaj, A. 2011. The impact of globalisation on South African higher education institutions. Pattern of academic inflow into South African higher education system. Delhi Business Review, 12(1): 37-50.

Mapesela, M.L.E. \& Strydom, F. 2005. Performance management of academic staff in South-African higher education: a developmental research project, OECD Conference held $25^{\text {th }}$-26th August 2005, Paris, France.

http://www.oecd.org/dataoecd/35/43/35327193.pdf [Accessed: 25 July 2015]

Matteus, A.M., Allen-Ille, C. \& Iwu, C.G. 2014. Skills shortage in South Africa. Interrogating the repertoire of discussions. Mediterranean Journal of Social Sciences, 3(6): 63-73.

Mbua, P. \& Sarisar, J.O. 2013. Challenges in the implementation of performance contracting initiative in Kenya. Public Policy and Administration Research, 3(2): 44-60. 
Ministry of higher education, 2004. A New Funding Framework: How Governments Grants are Allocated to Public Higher Institutions. Pretoria: Council on higher education.

Molefe, G.N. 2012. Performance measurements model and academic staff: A survey at selected Universities in South Africa and abroad. African Journal of Business Management, 6(15): 5249-5267.

Mulenga, C.N. \& Van Lill, B. 2007. Recruitment and selection of foreign professionals in the South African Job market: Procedures and processes. South African Journal of Human Resources Management, 5(3): 30-37.

Odhav, K. 2009. South African post-apartheid Higher Education policy and its marginalisation. 1994-2002. SA -eDUC Journal, 6(1): 33-57.

Organisation for Economic Co-operation and Development (OECD), 2013. OECD Economic Surveys: South Africa 2013. Westbank: OECD Publications.

Olumide, H.B. \& Ukpere, W.I. 2012. Brain drain and African development: Any possible gain from the drain? African Journal of Business Management, 6(7): 2421-2428.

Qi, G. \& Lange, G. 2005. Preventing Expatriate Failure. A Research on the Expatriate Selection and Training. Kristianstad: Kristianstad University.

Rassol, F. \& Botha, C.J. 2011. The nature, extent and effect of skills shortage on skills migration in South Africa: Original research. South African Journal of Human Resources Management, 9(1): 1-12.

Reguri, R.R. \& Lako, J.F. 2012. Work diversity, discrimination and harassment of expatriate academics in the South Pacific higher education. ILERA $16^{\text {th }}$ World Congress in $2^{\text {nd }}$ $-5^{\text {th }}$ July 2012, Philadelphia, USA.

Rabichund, S. \& Steyn, G.M. 2014. The contribution of the integrated quality management system to whole school development. Mediterranean Journal of Social Sciences, 5(4): 348-358.

Selmer, J. 2006. Language ability and adjustment: Western expatriates in China. Thunderbird International Business Review, 48(3): 347-368.

Steyn, A.G.W. \& De Villiers, A.P. 2005. Public funding of higher education in South Africa by means of formulae. In Council on Higher Education, Review of Higher Education in South Africa. Pretoria: Council on Higher Education, pp. 11-51.

Swanepoel, S.P., Botha, A. \& Makgonyane, N.B. 2014. Politicisation of performance appraisals. South African Journal of Human Resources Management, 12(1): 1-9.

Tahir, A.H. \& Ismail, M. 2007. Cross cultural challenges and adjustment of expatriates: A case study in Malaysia. Turkish Journal of International Relations, 6(3): 72-98.

Theron, M., Barkhuisen, N. \& Du Plessis, Y. 2014. Managing the academic talent void: Investigating factors in academic turnover and retention in South Africa. South African Journal of Industrial Psychology, 40(1): 1-14.

Toppo, L. \& Prusty, T. 2012. From performance appraisal to performance management. Journal of Business and Management, 3(5): 1-6.

Trading Economics, 2014. South Africa GDP. http://www.tradingeconomics.com/southafrica/gdp [Accessed: 05 May 2014]. 
Vlase, I. \& Voicu, B. 2014. High skilled immigrants in times of crisis. A cross European analysis. International Journal of Intercultural Relations, 42: 25-37.

Vogel, A.J. \& Millard, S.M. 2008. Preparation, support and training requirements of South African expatriates. South African Journal of Business Management, 39(3): 33-40.

Wangege-Ouma, G. \& Cloete, N. 2008. Financing higher education in South Africa: Public funding, non-government revenue and tuition fees. South African Journal of Higher Education, 22(4): 906-919.

Koenane, M.L.J. 2014. Towards an ethical contextualisation of Freud's theory of personality. Phronimon, 15(1): 1-15.

Kristeva, J. 1991. Strangers to Ourselves. LS Roudiez, New York: Columbia University Press.

Landau, L.B. (ed.). 2011. Postscript: positive values and the politics of outsiders. In Landau, L.B. (ed.), Exorcising the Demons Within: Xenophobia, Violence and Statecraft in South Africa. Johannesburg: Wits University Press.

Letseka, M. 2013. Anchoring Ubuntu morality. Mediterranean Journal of Social Sciences. 4(3): 351-359.

MacIntyre, A. 2007. After Virtue, $3^{\text {rd }}$ edn. London: Gerald Duckworth \& Co. Ltd.

Mail \& Guardian and University of South Africa Critical Thinking Forum, 2015. "Bizos: 'I know, too, what it means to be a foreigner'”. http://mg.co.za/article/2015-04-23-bizosi-know-too-what-it-means-to-be-a-foreigner [Accessed: 30 May 2015].

Mudimbe, V.Y. 1988. The Invention of Africa: Gnosis, Philosophy, and the Order of Knowledge. Blooming and Indianapolis: Indiana University Press.

Nyamnjoh, F.B. 2006. Insiders and Outsiders: Citizenship and Xenophobia in Contemporary Southern Africa. London and New York: CODESARIA Books in Association with Zed Books.

Pogge, T. 2006. Migration and poverty. In Gooding, R.R. \& Pettit, P. Contemporary Political Philosophy: An Anthology, $2^{\text {nd }}$ edn. Malden, MA: Black Publishing.

UNHCR, 2009. UNHCR Statistical Yearbook. www.unhcr.org/ [Accessed: 08 October 2015].

United Nations High Commission for Refugees (UNHCR), 2010. Convention and Protocil Relating to the Status of Refugees. Geneva: UNHCR.

Wilson, T.D. 2002. Strangers to Ourselves: Discovering the Adaptive Unconsciousness. Boston, MA: Harvard University Press.

Wilson, K. 2015. Analysis: Are Foreigners Stealing Jobs in South Africa? https://www.africacheck.org/...analysis_are_foreigners_stealing_jobs_in_south_africa / [Accessed: 08 October 2015]. 